\title{
5. BESSARABIAN IN THE MODERN ENGRAVING CONSTITUTION AND INTERFERENCE WITH ITS EUROPEAN ART
}

\author{
Iarîna Savițkaia-Baraghin 270
}

\begin{abstract}
Runing the new century $(X X)$ attests in Bessarabian art, the experience of several decades of professional artistic activity (the first Evening School of Drawing appears in Chisinau in 1887 and is due scholar Academy of Arts in St. Petersburg, Terinte Zubcu). Such short experience has not met any of the neighboring countries' national schools. In Bessarabia from the beginning of the twentieth century is established the main areas of professional art-painting- with remarkable portraits, landscapes, genre paintings; sculpture with respective genres; stampa as a kind of graphics. Marked by the period and by the influences of art schools, where Bessarabians have studied, it is clear that in painting and sculpture and graphics in the first round, have dominated peredvizhnik influences their color and monochrome theme. Guidelines of Bessarabian plastic artists in the development phase of modern art, is the decisive moment of establishment of the Bessarabian engraving as a kind of professional art, marked by tendencies that have appeared in European art and Russian at the limit of nineteenth and twentieth centuries, such as Expressionism in the works of Sneer Cogan, George Ceglocof and Art 1900 in the works of Theodor Kiriacoff, Elisabeth Ivanovsky or Moissey Kogan.
\end{abstract}

Key words: engraving, art school, artists, exhibition, artistic center

\section{Introduction}

Developing as artistic phenomenon in the Russian culture and European ambiance, but spaced considerably in time and space, Bessarabian modern art has its beginnings in the 90s of the nineteenth century and is considered as a process of 2-3 decades of twentieth century, marking the first appearance of professional artists on our land. Most of them were from Bessarabia and this moment was fully revealed in the way of reflecting picturesque reality of the landscape.

Bessarabian engraving in modern times and its interference with European art continues to be known only in general, as well as other kinds of arts. There are known authors and works discovered in Chisinau and Bucharest's museums, in the archives of Estampa Ofice of the Romanian Academy and in National Archive of Republic of Moldova. Thus, while providing a solid background of works, engraving permanently identify with the general notion of graphics or prints, easel graphic or lithography. Therefore, the kind of art concerned is diverse and "diluted" in the ambiance of other areas, remains little known both in the local and in neighboring artistic space, being in the shadow of all artistic events in Chisinau. This point is reflected by the artists and their works even in moment of appearance of Bessarabian professional engraving in the interwar period. Initially, engraving has reflected in miniature styles and general trends in

\footnotetext{
${ }^{270}$ Senior Lecturer PhD., Academy of Music, Drama and Visual Arts Chișinau, Republic of Moldavia, email: siarina2002@yahoo.com
} 
European art of the respective epoch, selectively addressing the general topic, characteristic to the genre, but also having its specific peculiarities.

\section{Discussions}

Studying the creative activities, and exhibitions of Basarabians convince us that under the influence of itinerant exhibitions in Chisinau is established the Amateur Arts Society of Bessarabia (1903), among its founders appearing Vasile Blinov, Alexander Climaşevschi and Vladimir Ocuşco ${ }^{271}$. The creation of this first association following the model on those structures in Russia and Ukraine was an important phenomenon for the local culture, encouraging professional development of Bessarabian professional art.

With the change of political situation, following the union of Bessarabia and Romania, artistic life is increasing in the area of Bessarabian painters interests pervade Western art styles and guidelines. At the initiative of Alexander Plămădeală, and Vladimir Donchev, Auguste Baillayre and former members of the Amateur Arts Society in 1921 in Chisinau is founded Fine Arts Society of Bessarabia ${ }^{272}$.

And the first, and second company, appeared in Chisinau, were based inside the urban Drawing School, and later - at the School of Fine Arts, being permanent centers of artistic activity in Bessarabia. Professional art, including engraving, appeared in Orthodox environment due to founding artistic education institutions, which stimulated the emergence of art genres, reported to the European ones but also those areas that represented. This process has developed differently in different regions, sometimes at distances of decades.

Thus the beginnings of the specialized studies in the Principality of Moldavia are inextricably linked to the name of Gheorghe Asachi (Mihaileanu Academy in Iasi, 1839) and Gheorghe Panaiteanu Bardasare, who founded the Fine Arts School in Iasi (1864) ${ }^{273}$. In Bessarabia, as it is known, the occurrence of initial training forms of fine arts dates back to only the 1887, at a considerable distance for the creation of such institutions in neighboring countries. It is these complex moments and stylistic of certain guidelines issued identification, that show only by the first decade of the twentieth century, they have conditioned the appearance of late modern art and engraving Bessarabia.

The beginning of the new century (XX) attest Bessarabian art only a decade of experience and a professional activity (the first evening school of drawing appears in Chisinau in 1887 and is due to Terinte Zubcu Fellow of the Academy of Arts in St. Petersburg) ${ }^{274}$. Such short experience, probably not known any of the neighboring countries' national schools. A brief crossing overview of the most important motivations in the emergence and evolution of the early Bessarabian arts allows us to follow, in terms of comparison,

\footnotetext{
${ }^{271}$ Plămădeală A. Artişti plastici basarabeni - un scurt istoric. În: Viaţa Basarabiei, 1933, nr. 11, p.50

${ }^{272}$ Plămădeală A. Op. cit., p. 47

${ }^{273}$ Drăguţ V., Florea V., Grigorescu D., Mihalache M. Pictura românească în imagini. Bucureşti: Meridiane, 1970. p. 140

${ }^{274}$ Cezza L. Плоды с дерева дружбы. Кишинев: Timpul, 1964, p. 53
} 
conducted in different ambiance artistic situation in Western Europe and the East.

In general, modern art in Bessarabia experienced two major stages of its evolution that coincide with certain historical periods: the first shall cover the years held in the composition of Tsarist Russia with the status of province (1812-1918); the second related to the composition of the United Romanian Bessarabia reintegration (1918-1940). The first phase marks the establishment of modern art, which reaches its climax of development in the second stage. Along with artistic centers Russian and Ukrainian at the beginning of the twentieth century a special role in the artistic process of Bessarabia have played major cultural capitals of Western Europe - Paris, Munich, Amsterdam and Brussels, where over several decades have continued their studies Bessarabian painters ${ }^{275}$.

The Avantguard has become attractive especially for young artists, who went to continue their studies in art academies which have been operating in this period artistic centers of Western and subsequently became promoters of new trends in their countries of origin as universality experiments in arts. But undoubtedly the biggest and most prestigious center of European art during the period concerned was Paris. By the late nineteenth century and the beginning of the twentieth century, it becomes hub of international art, where arrives to demonstrate their skill and to acquire fame, artists from various geographical areas - from South and the North America, from Japan, especially from the European area, where probably every country has had its representatives in France. School of Fine Arts, where studied many of Impressionist and future Symbolist, fauvist and even avant-garde, was not the only institution of artistic education in Paris. Here functioned workshops and private academies that offered training and knowledge for exams in state institutions. But many prospective artists who studied in the Swiss, Julian, Grande Chaumiere, Common Academies or in the studio of Gleyre or Gerome usually no longer continue their studies remaining to create in Paris and returned to their countries.

Paris, with the famous Montparnasse and Montmartre, with the official salons and independent salons of autumn and spring, with the traditional academicist opposition exhibitions were viewed and commented different by painters from Bessarabia. Among them we can mention Eugenia Maleşevschi and before she Auguste Baillayre, Lidia Arionescu, Piotr Vaxman only and Alexandr Patlagean, Oles Hrşanovschi, Gregoire Mişonze, Zelman, Iosiph Bronstein, Moissey Kogan, which are just the first wave of Bessarabia representatives, who have studied or visited Paris ${ }^{276}$. Another important cultural center of the time was Munich. Closer to the Bessarabia, but farther than France, Belgium or the Netherlands, where one spoke French, which Bessarabians were familiar from childhood, the Bavarian capital hosted only a few Bessarabian brothers Sneer and Moissey Kogan, who study at the Academy of Arts here on

\footnotetext{
275 Stavilă T., Arta plastică modernă din Basarabia. Chişinău: Ştiinţa, 2000, p. 80

${ }^{276}$ Idem, p. 83
} 
the border of the centuries - between 1899 and $1903^{277}$. For Moissey Kogan Bayern period, however, it lasts until 1910.

Among outstanding phenomena manifested in Munich at this time, a special place is occupied the secession, the initial phase of which ends up on arrival of brothers in Germany (1897), but both of the cosmopolitanism of the city is due to the journal Simplicissimus (1896) and occurrence Judentstil's used as a term for the first time in 1899 by Rudolf A. Schröder in a magazine Insel text. ${ }^{278}$. Almost two decades later makes its appearance in Germany, but in a different city, Dresden, another Bessarabian - George Ceglocoff that between the years 1923-1926 studied at the Academy of Arts, almost the same time when activated here as a teacher Oscar Kokoschka (1919-1924) and also where in 1919 enabled representatives of secession, Otto Dix, Constantin Felixmüller and Otto Lange and her colleague Hans Grundig being ${ }^{279}$. In the neighborhood there is another capital, where confirming the presence of Bessarabians - Brussels, who assaulted this town after 1920 Auguste Baillayre students from the School of Fine Arts in Chisinau. Moisei Gamburd, Elisabeth Ivanovsky, Nina Jaşicinski, Claudia Cobizev Afanasie Modval graduate of Royal Academy of Arts in the period 1928-1936, their works, mostly representing different variants of French art - from realism of Gustave Curbet to Kasimir Malevich's constructivism. ${ }^{280}$.

Last artistic center, where Bessarabians not only studied and exposed after 1920 as well settled down to live after 1945, was Bucharest. It might sound paradoxical, but the relationship between the artistic and the Kingdom of Romanian Bessarabia after the Union of 1918 was much less beneficial than could be expected. True, in 1921-1922 the exhibition of Bessarabian painters is inaugurated in Bucharest, many of which have been mentioned. But the response of the Bucharest exhibition was organized only in 1930. However, Bessarabians participate in official salons in Bucharest, studied at the Academy of Arts, being mentioned with the scholarships to study in France, Belgium, Italy. Possibly, such a situation was a direct consequence of the influence of Eastern art, quite evident in the works of painters from Bessarabia. But common interests, characteristic of both regions, new trends and new directions, is approaching on plastic artists, equally with those of Russia, France and Ukraine, which is due to the national and Western arts synchronization. Last landmark, which Bessarabian art owes new breath in art trends, was Odessa, a city of specific cultures, which in the early twentieth century culture has a weight far greater than Kiev.

Traditional exhibition of the Association of Painters of Southern Russia, organized in Chisinau by the end of the nineteenth century, tempt many Bessarabian - Michael Berezovschi, Paul Piscariov, Paul Şilingovschi and others - to attend exhibition openings in Odessa. Another role Odessa played by Art

\footnotetext{
${ }^{277}$ Allghemeines Lexicon der Bildenen Kunstler, theime - Beker, 1927, p. 197-198

${ }^{278}$ Elias J. Das zehnte Berliner Sezessionejahr. În: Kunst und Kunstler, vol. VII, 1909, p. 389-405

279 Stavilă T. Gravorul Gheorghe Ceglocoff. În: Arta, Chişinău, 2008, p. $72-89$

${ }^{280}$ Stavilă T., Arta plastică modernă din Basarabia. Chişinău: Ştiinţa, 2000, p. 83
} 
School. Here have studied Sneer Cogan, Nicolai Gumalic, Paul Şilingovschi, Paul Piscariov, Georghe Damira, Timothy Koltai and others. Here takes place in 1909, the famous "Salon" of Vladimir Izdebsky with the participation of Russian and French avanguard, later exposed to Kiev and St. Petersburg.

\section{Conclusions}

In Bessarabia from the beginning of the twentieth century are pursuing the influences also of other companies and artistic trends, certified in Russia and Western Europe. A special role was played by Mir iskusstva, postImpressionism and Art Nouveau principles of that approach are traceable in Plastic Artists creation Bessarabian until 1940. These moments are strongly evident in creations of Eugenia Maleşevschi, Auguste Baillayre, Paul Şilingovschi, Vladimir Donchev, Lidia Arionescu etc. Specific is the tendency of many Bessarabian to manifest in various fields and genres of creation. Besides the paintings, many of them professed stage design, book graphics and easel painting, sculpture, decorative art and art criticism. Some Bessarabian plastic artists, such as Pavel Şilingovschi and Auguste Baillayre have reached the level of European art in their work and occupies an important place in the artistic process of the country.

\section{References}

1. Adiasevici, V. (1933). Bessarabschii ănţiclopediceschii slovari. În: ANRM, F.792, Ch.

2. Arhiva Organizaţiilor social-politice din Chişinău. F. 2906, r, 1, d.1, 10 p.

3. Baillayre Auguste. Arhiva Naţională a Moldovei. În: ANRM, F., 2989, r.1, d.1-64

4. Cezza L. Плоды с дерева дружбы. Кишинев: Timpul, 1964, p. 53

5. Cogan Şneer. Arhiva Naţională a Moldovei. În: ANRM, F.2117. r.1

6. Barbas, E. (2007). Pavel Şilingovschi. Chişinău: Arc

7. Florea, V. (1979). O istorie a artei ruse. Bucureşti: Meridiane

8. Goncearov, A. (1963). Arta graficii. Bucureşti: Meridiane

9. Miron, S. (2012). Stampa Moldovei (1954-1996) din colecţia de artă şi hărţi a Bibliotecii Naţionale. Chişinău: Biblioteca Naţională a Republicii Moldova

10. Plămădeală, A. (1933). Artişti plastici basarabeni - un scurt istoric. Viaţa Basarabiei, 11, 50

11. Stavilă, T. (2000). Arta plastică modernă din Basarabia. Chişinău: Ştiinţa

12. Stavilă, T. (2008). Gravorul Gheorghe Ceglocoff. Arta, Chişinău, 72-89

13. Асеева, Н. (1989). Украинское искусство и художественные центры. Kiev: Мистецтво

14.Гольцов, Д. (1971). Художественная жизнь Молдавии. Кишинев: Картя молдовеняскэ

15.Гольцов, Д., Зевина А., Лившиц М, еtс. (1967). Искусство Молдавии. Кишинев: Картя молдовеняскэ

16. Мишина, Е. (2004). Московская школа гравюры XVII - начала XVIII века. [Teza de doctor habilitat în studiul artelor]. Санкт-Петербург

17. Стернин, Г. (1970). Художественная жизнь России на рубеже ХІХ-ХХ веков. Москва: Искусство

18. Ісаєвич, Я. (2002). Українське книговидання: витоки, розвиток, проблеми. Львів: Ін-т українознавства ім. І. Крип'якевича НАН України 